\title{
The Potential of Breadfruit Seed and Jackfruit Seed as Alternative Replacement Medium of Potato Dextrose Agar (PDA) with Seedling Fo Mushrooms
}

\author{
SUPARTI $^{1 *}$, LINA AGUSTINA ${ }^{1}$, PUTRI AGUSTINA $^{1}$, RESTI RAHMAWATI $^{1}$ \\ ${ }^{1}$ Department of Biology Education, Faculty of Teacher Training and Education, Universitas Muhammadiyah Surakarta \\ Jl. A. Yani Tromol Pos 1 Pabelan Kartasura, Sukoharjo, Indonesia.57162 \\ *Email:sup168@ums.ac.id
}

Received 23 September 2018; Received in revised form 18 April 2019; Accepted 23 June 2019; Available online 30 June 2019

\begin{abstract}
Potato Dextrose Agar (PDA) is the most media to grow the mushrooms, but the price of this media is expensive. Thus we need alternative media that easy and cheap to get it. This study aims to determine the growth of Aspergillus niger in alternative Artocarpus communis and Artocarpus heterophyllus seeds media. This research was an experimental study using a completely randomized design (CRD) one factor was the type of media is PDA (M0), Artocarpus communis seed media (M1), Artocarpus heterophyllus seed media (M2) and using the test mushrooms A. niger (J1). Inoculation of A. niger used agar block method for 3 days with a temperature of $28^{\circ} \mathrm{C}$. Parameter of research was colony diameter and sporulation of A. niger. Data obtained with qualitative and quantitative methods. The result of this research showed that the best growth for Aspergillus niger was after 72 hours incubation. Colony diameter continually in PDA media, Artocarpus communis media, and Artocarpus heterophyllus media is $4.7 \mathrm{~cm}, 4.3 \mathrm{~cm}$, and $4.1 \mathrm{~cm}$ with heavy sporulation. Therefore, Artocarpus communis and Artocarpus heterophyllus seeds media can be utilized as a substitution of PDA media for the growth of mushrooms.
\end{abstract}

Keywords: Artocarpus communis seeds; Artocarpus heterophyllus seeds; media for mushroom growth, PDA

\section{INTRODUCTION}

Medium is a material consisting of food substance mixture (nutrient) which functions as place for microbes to grow. Beside for growing microbes, the medium can also be used for isolating, multiplying, testing physiological properties and calculating the number of microbes. One of microorganisms that frequent to culture in microbiology, both in food and agricultural industry, are mushrooms. Mushrooms are frequently cultivated using PDA (Potato Dextrose Agar) medium (Nasim et al., 2001; Muthu \& Shanmugasundaram, 2015). PDA is a common medium for mushroom growth in the laboratory, adjusted to a low pH (4.5 to 5.6) (Sharma \& Pandey, 2010; Fasola et al., 2007). This characteristic can inhibit bacterial growth that requires neutral environment with $\mathrm{pH} 7.0$ and optimum temperature between $25^{\circ} \mathrm{C}-30^{\circ} \mathrm{C}$.

Based on its composition, PDA is categorized as semi-synthetic media because it is composed of natural material (potato) and synthetic material (dextrose and agar) (Griffith et al., 2007; Maharani et al., 2004), also used for establishment of single isolated colonies (Bailes et al., 2013). Potato is source of carbon (carbohydrate), vitamins, and energy, then dextrose is source of sugar and energy, while agar is used for solidifying PDA medium (Hoa \& Wang, 2015; Suzuki \& Iwahashi, 2016). Each of the three components is very necessary for the growth and proliferation of microorganism, especially mushrooms.

Mushroom growth and development is influenced by many factors such as temperature, light, air, $\mathrm{pH}$ and nutrients like carbon and nitrogen, and simple carbohydrate. Semi-synthetic media like PDA has sufficient carbohydrate so it is good for mushroom growth. This medium is needed a lot for mushrooms propagation in laboratory and agriculture. While the need for PDA is increasing, the price of this medium is quite expensive and this medium is not sold in all chemical stores. It is necessary to find alternative for replacing mushroom growth medium. 
Carbon source from carbohydrate and protein are widely used by researchers to make alternative mushroom growth medium like cassava starch (Kwoseh et al., 2012); White and purple sweet potatoes, cocoyam and yam (Amadi et al., 2012); Cowpea, black soybeans and green beans (Ravimannan et al., 2014). There are many sources of carbohydrates from raw material and waste material those are cheap and easy to get but not yet optimized as mushroom culture medium, especially breadfruit seed and jackfruit seed. Breadfruit seed and jackfruit seed have many nutrients especially high source of carbohydrates. Breadfruit seed has 5.7 grams carbohydrate and jackfruit seed has 36.7 gram carbohydrate (Depkes RI, 2011). Based on the description above, researcher intends to utilize carbohydrate source from breadfruit seed and jackfruit seed as substitution of mushrooms growth medium.

\section{MATERIALS AND METHODS}

This research was done at Laboratory of Biology, Universitas Muhammadiyah Surakarta. This research was an experimental study using a completely randomized design
(CRD) with one factor of medium treatment. The medium that used were PDA as control medium, breadfruit seed and jackfruit seed as test medium which each of medium was carried out 3 times test. Mushroom that was used in this research was $A$. niger.

This research implementation began with sterilization of equipment that was used, and then made 300 gr extract of breadfruit seed and jackfruit seeds in $1000 \mathrm{ml}$ distilled water, and then continue with added 20 gr sugar and 20 gr agar in extract and finally this medium was sterilized. Furthermore, sample of $A$. niger mushrooms was inoculated used agar block method with cork borer in incubation at $28^{\circ} \mathrm{C}$ for 72 hours. Diameter of colonies and sporulation were calculated every 24-hours interval. Data were analyzed with qualitative and quantitative methods by making observation mushrooms diameter of colonies and sporulation.

\section{RESULT AND DISCUSSION}

Result of research on utilization breadfruit seed and jackfruit seed as PDA medium substitution for mushrooms (A. niger) growth is presented in Table 1.

Table 1. The Growth of multicellular mushrooms (A. niger) in alternative medium (Breadfruit Seed and Jackfruit Seed)

\begin{tabular}{ccccc}
\hline \multirow{2}{*}{ Treatment } & \multicolumn{2}{c}{ Average diameter $(\mathbf{c m})$ of the colony at hour incubation } & \multirow{2}{*}{ Sporulation } \\
\cline { 2 - 4 } & $\mathbf{2 4}$ & $\mathbf{4 8}$ & $\mathbf{7 2}$ & Dense \\
\hline M0 & 1.2 & 2.7 & 4.7 & Dense \\
\hline M1 & 1.2 & 2.8 & 4.3 & Dense \\
\hline M2 & 1.2 & 2.5 & 4.1 & Denn
\end{tabular}

M0: A. niger on PDA medium (control)

M1: A. niger on breadfruit seed medium (alternative)

M2: A. niger on jackfruit seed medium (alternative)

Table 1 shows mushroom colony growth on breadfruit seed and jackfruit seed as alternative substitution of PDA medium that marked with increasing diameter of $A$. niger. The longer incubation time, mushroom sporulation will be denser. The biggest colony diameter is found on PDA medium that is 4.7 $\mathrm{cm}$ and the smallest colony diameter is found on jackfruit seed that is $4.1 \mathrm{~cm}$. Colony diameters that found in breadfruit seed and jackfruit fruit as alternative medium show the same growth rate with PDA medium as control medium. The order of $A$. niger colony diameter from the biggest to the lowest is PDA medium, breadfruit seed medium and jackfruit seed (Figure 1). 


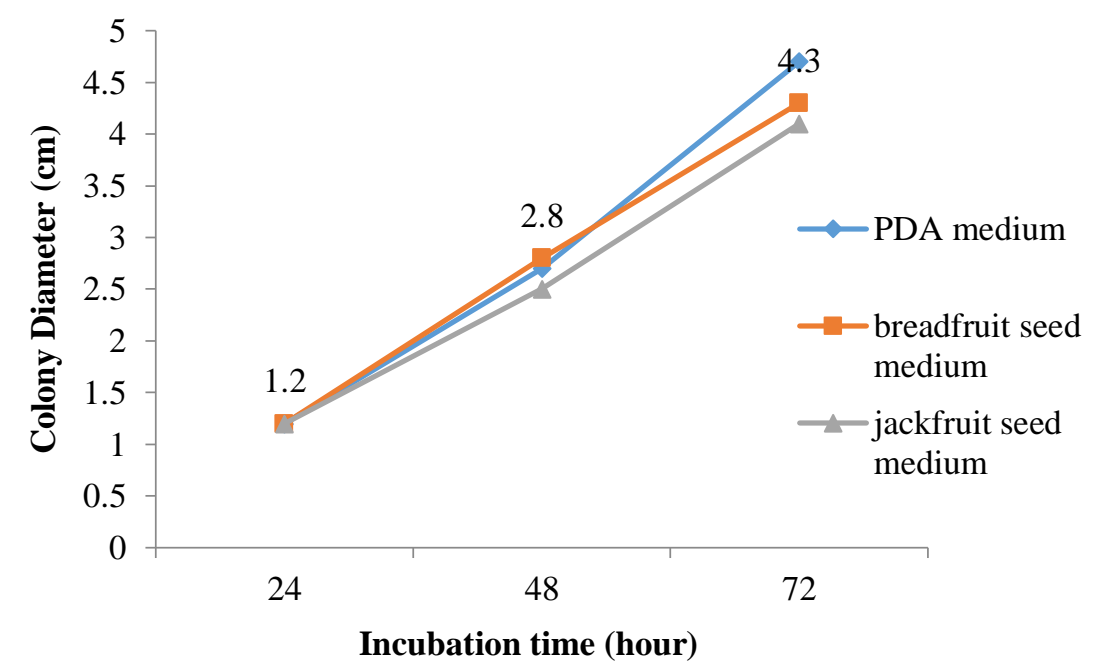

Figure 1. A. Niger diameter colony graphic

Based on result and observation that are done to A. niger, it showed mushroom have growth day by day that marked with increasing of mushroom colony diameter. Besides observation of colony diameter, A. niger growth also can be observed by appearance of sporulation. On the PDA medium, breadfruit seed medium and jackfruit seed medium, $A$. niger has dense sporulation and optimal growth that marked with the formation of white compact layer on the bottom of medium and the formation of sporulation like black powder with brown to black colored, roughly and round shaped (Gupta et al., 2012).

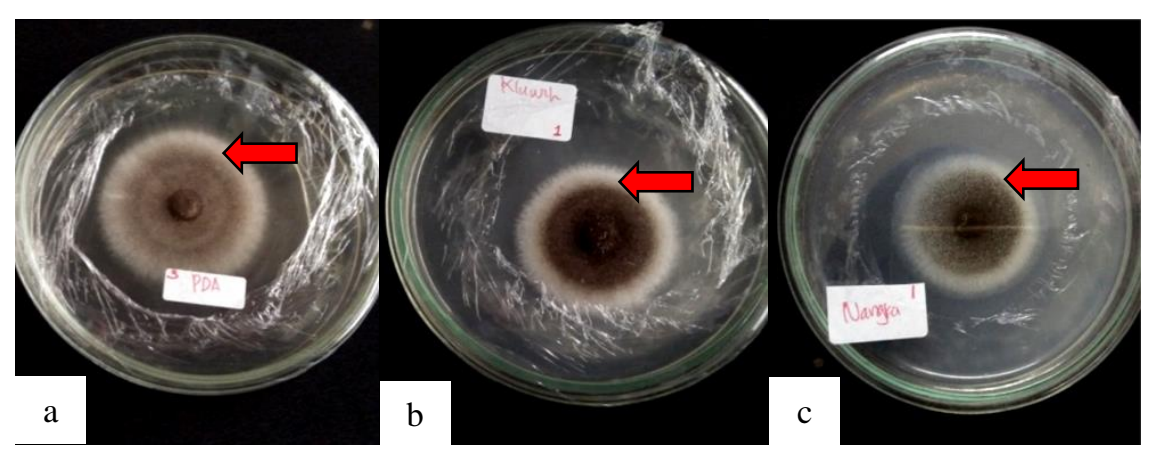

Figure 2. A. niger Growth after 72 hours incubation. a. PDA; b. breadfruit seed; c. jackfruit seed (arrow shows sporulation formed)

Based on observation of Image 2, it shows mushroom growth after 72 hours incubation. Each medium shows increase in colony diameter marked with growth of bigger mycelium and formed of dense spores (sporulation). A. niger can grow quickly with nutrients around it. Growth medium of $A$. niger can be considered as good if that medium can boost mycelium and sporulation growth. Sporulation growth from breadfruit seed and jackfruit seed as alternative medium is almost same with PDA medium. The best sporulation is on breadfruit medium, then on PDA medium and the least is on jackfruit seed.

PDA medium was used as control or comparison mushroom growth medium for breadfruit seed and jackfruit seed medium. PDA medium is simple medium that consists of potato extract, dextrose, and agar. This medium is good to support mushroom growth because it has low acid characteristic ( $\mathrm{pH} 4.5$ to 5.6) that prevent bacterial contamination. Bacterial growth or contamination can occur in neutral environment with $\mathrm{pH}$ 7.0. A. niger growth on breadfruit seed and jackfruit seed as alternative 
medium show optimal result and the growth almost same with control medium (PDA). This is because breadfruit seed and jackfruit seed have the nutrients that needed for mushroom growth, especially carbohydrate. Carbohydrate that contained is the main substrate for mushroom growth, especially as carbon source in its metabolism system. Nutrients comparison of breadfruit seed and jackfruit seed is shown in Table 2.

Table 2. Nutrition Content per 100 grams Jackfruit Seed and Breadfruit Seed (Hettiaratchi et al., 2011; USDA, 2015)

\begin{tabular}{clcc}
\hline No. & \multicolumn{1}{c}{ Nutrition Component (unit) } & Jackfruit Seed & Breadfruit Seed \\
\hline 1 & Energy (kkal) & 165 & 247 \\
\hline 2 & Protein (g) & 4.2 & 9.8 \\
\hline 3 & Fat (g) & 0.1 & 5.9 \\
\hline 4 & Carbohydrate (g) & 36.7 & 52.7 \\
\hline 5 & Calcium (mg) & 33 & 53 \\
\hline 6 & Phosphor (mg) & 200 & 6.2 \\
\hline 7 & Iron (mg) & 1.0 & 26 \\
\hline 8 & Vitamin A (SI) & - & - \\
\hline 9 & Vitamin B1 (mg) & 0.2 & 6.6 \\
\hline 10 & Vitamin C (mg) & 10 & - \\
\hline 11 & Water (g) & 57.7 & \\
\hline
\end{tabular}

Based on Table 2, it shows that breadfruit seed has highest nutrition component per 100 grams with content of carbohydrate is 52.7 grams while jackfruit seed only has 36.7 grams. Breadfruit seed has more carbohydrate content, so the growth of A. niger colony is more optimal while comparing with growth of colony in jackfruit seed. Carbohydrate is generally found in nature as oligosaccharides and polysaccharides and usually as backup nutrient for the plant. Mushroom depends on that complex carbohydrate as source of nutrient. That complex carbohydrate is broke down into monosaccharide form with extracellular enzymes before absorbed by mushroom for further assimilation.

Based on research that is done by Aini (2015), derived mediums from canna (Canna discolor L.) bulbs, yam (Dioscorea esculenta L.) bulbs and arrowroot (Maranta arundinacea) can support $A$. niger growth so can be used as alternative medium of PDA. Based on this research the best alternative medium is yam bulbs with 1.84 grams carbohydrate content. Whereas based on research that is done by Faradina (2016), derived mediums from arrow leaf elephant ear (Xanthosoma sagittifolium) bulbs and elephant foot yam (Amorphophallus paeoniifolius) bulbs can be used as alternative medium of PDA because those media can support $A$. niger growth. Based on this research, the best alternative medium for PDA is arrowleaf elephant ear bulbs with 34.2 grams carbohydrate content and longer incubation periods. Mediums that derived from various bulbs above can be used as substitution of PDA medium, but $A$. niger growth has not been as optimal as PDA medium, because the resulting mushroom has thin sporulation.

Based on result, derived mediums from breadfruit seed and jackfruit seed can be used as substitution or alternative medium of PDA (Potato Dextrose Agar) medium because those media can support mushroom growth. Medium from breadfruit seed is more effective as substitution of PDA medium because A. niger growth in this media almost same with $A$. niger growth in PDA medium in the same incubation periods.

\section{CONCLUSION}

Based on the result of research that has been done about breadfruit seed and jackfruit seed utilization as substitution of PDA medium for mushroom growth, can be concluded that medium from breadfruit seed and jackfruit seed can be used as substitution of PDA medium to grow A. niger. Recommendation from this research are pay attention with maturity level of used seed, pay attention with extraction process of alternative medium and further research about PDA medium substitution using another 
source of nutrients and another mushroom is needed.

\section{REFERENCES}

Aini N. 2015. Media alternatif untuk pertumbuhan bakteri menggunakan sumber karbohidrat yang berbeda. [Skripsi]: Surakarta: Universitas Muhammadiyah Surakarta.

Amadi OC, and Moneke AN. 2012. Use of starch containing tubers for the formulation of culture media for fungal cultivation. African Journal of Microbiology Research. vol 6(21): 4527-4532. doi: 10.5897/AJMR12.097.

Bailes G, Lind M, Ely A, Powell M. MooreKucera J, Miles C, Inglis D, Brodhagen M. 2013. Isolation of Native Soil Microorganisms with Potential for Breaking Down Biodegradable Plastic Mulch Films Used in Agriculture. Journal of Visualized Experiments. vol 75: 50373. doi: https://dx.doi.org/10.3791\%2F50373.

Direktorat Bina Gizi. 2011. Info pangan dan gizi. vol xx(1): 1-78. Jakarta: Kementerian Kesehatan Republik Indonesia.

Fasola TR, Gbolagade JS, Fasidi IO. 2007. Nutritional requirements of Volvariella speciose (Fr. Ex. Fr.) Singer, a Nigerian edible mushroom. Food Chemistry. vol 100(3): 904-908. doi: https://doi.org/10.1016/j.foodchem.2005.1 0.061 .

Griffith GW, Easton GL, Detheridge A, Roderick K, Edwards A, Worgan HJ, Nicholson J, Perkins WT. 2007. Copper deficiency in potato dextrose agar causes reduced pigmentation in cultures of various fungi. FEMS Microbiology Letters. vol 276(2): 165-71. doi: 10.1111/j.15746968.2007.00923.x.

Kwoseh CK, Darko MA, Abudofour K. 2012. Cassava starch-agar blend as alternative gelling agent for mycological culture media. Bots. J. AgriApplScl. vol 8(1): 8-15.

Faradiana R. 2016. Pemanfaatan sumber karbohidrat yang berbeda (umbi kimpul dan umbi suweg) sebagai substitusi media PDA (Potato Dextrose Agar) untuk pertumbuhan jamur. [Skripsi]. Surakarta: Universitas Muhammadiyah Surakarta.

Gupta M, Manisha K, Grover R. 2012. Effect of various media on types on the rate of growth of Aspergillus niger. Jurnal Fundamental and Applied Life. vol 2(2): 141-144.

Hettiaratchi U, Ekanayake S, Welihinda J. 2011. Nutritional assessment of a jackfruit (Artocarpus heterophyllus) meal. Ceylon Medical Journal. vol 56(2):54-8. doi: 10.4038/cmj.v56i2.3109.

Hoa HT, and Wang CL. 2015. The Effects of Temperature and Nutritional Conditions on Mycelium Growth of Two Oyster Mushrooms (Pleurotus ostreatus and Pleurotus cystidiosus). Mycobiology. vol 43(1): 14-23. doi: https://dx.doi.org/10.5941\%2FMYCO.201 5.43.1.14.

Maharani MM, Ratnaningtyas NI, Priyanto S. 2014. Penggunaan beberapa medium semisintetik untuk produksi miselium jamur maitake (Grifola frondosa (Dickson: Fr.) S. F. Gray) isolat Cianjur dan ekstrak kasarnya. Scripta Biologica. vol 1(1): 2025. doi: https://doi.org/10.20884/1.sb.2014.1.1.20.

Muthu N and Shanmugasundaram K. 2015. Effect of five different culture media on mycelial growth of Agrocybe aegerita. Int J Pharm Sci Res. vol 6(12): 5193-97.doi: 10.13040/IJPSR.0975-8232.6(12).519397.

Nasim G, Malik SH, Bajwa R, Afzal M, Mian SW. 2001. Effect of three different culture media on mycelial growth of oyster and chinese mushrooms. Journal of Biological Sciences. vol 1(12): 1130-1133. doi: 10.3923/jbs.2001.1130.1133.

Peraturan Menteri Kesehatan RI. 2013. Angka kecukupan gizi yang dianjurkan bagi bangsa Indonesia. Lampiran Peraturan Menteri Kesehatan Republik Indonesia Nomor 75 Tahun 2013.

Ravimannan N, Arulanantham R, Pathmanathan S, Niranjan K. 2014. Alternative culture for fungal growth using different formulation of protein sources. 
Annals of Biological Research. vol 5(1): 36-39.

Sharma G, and Pandey RR. 2010. Influence of culture media on growth, colony character and sporulation of fungi isolated from decaying vegetable wastes. Journal of Yeast and Fungal Research. vol. 1(8): 157164.
Suzuki T, and Iwahashi Y. 2016. Addition of carbon to the culture medium improves the detection efficiency of aflatoxin synthetic fungi. Toxins. vol 8(11): 338. doi: https://dx.doi.org/10.3390\%2Ftoxins8110 338.

USDA. 2015. Nutrient Database. https://ndb.nal.usda.gov/ndb/. Online access January 2019. 